\title{
Cultivating the Value of Empathy in the Family Develops a Self-Compassion Attitude in Children
}

\author{
Wulan Patria Saroinsong ${ }^{1, *}$, Chinun Boonroungrut ${ }^{2}$, Brwa Aziz Sidiq $^{3}$, Cantika Ayu \\ Meylinda $^{1}$, Difta Laily Fauziyah ${ }^{1}$, Lisfi Wulandari ${ }^{1}$ \\ ${ }^{1}$ Department of Early Childhood Education Teacher Education, State University of Surabaya, Surabaya, Indonesia \\ ${ }^{2}$ Department of Educational and Development Psychology, Silpakorn University, Bangkok, Thailand \\ ${ }^{3}$ Department of English Languages, University of Human Development, Sulaimani, Kurdistani Region, Irak \\ *Corresponding author.Email: wulansaroinsong@unesa.ac.id
}

\begin{abstract}
One of the problems of early childhood is that there are still children who have not developed a self-compassion attitude. This can be seen from the attitude of everyday children who easily blame themselves when faced with failure, do not want to correct mistakes, and are less able to manage their emotions. This study aims to describe the cultivation of the value of empathy in the family to develop self-compassion in children. This study involved as many as 226 parents of children aged 2-6 years. This study uses a quantitative approach using descriptive statistics. The main findings reveal that the effectiveness of inculcating the value of empathy on self-compassion is influenced by factors of gender, age, and personality of the child.
\end{abstract}

Keywords:: Empathy, Self-Compassion, Children

\section{INTRODUCTION}

Early childhood is an individual who is undergoing a very rapid development process with different potentials. Early childhood is in the golden age in the age range of human development. It is at this time that the development of children in various aspects experiences a very fast process. This potential can be developed through educational stimulation so that it can form more qualified individuals.

The education given to children is not only obtained from the school. Education can be obtained from the family environment. The family is the smallest community of society that acts as the first and foremost place for children. A child begins to receive lessons in ethics, morality, and other life values from the family that tend to be remembered more than formal educational institutions.

From the family, children will receive empathy education that is beneficial for their lives. As social beings, everyone will need each other. As children know as part of

Social beings in their lives need each other. One of the factors that form the basis of successful social interactions is empathy. Empathy in English comes from the Greek "empatheia", which means to feel. Empathy is the ability to understand other people's feelings and problems, think from their point of view, and appreciate the different feelings of other people about various things [1].

By having empathy, the child will grow selfcompassion. Self-compassion is a concept adapted from the Buddhist philosophy of loving yourself like pity when you see others experiencing difficulties. Self-compassion is an attitude of having concern and kindness towards oneself when faced with various difficulties in life or towards shortcomings in oneself and understanding that suffering, failure, and shortcomings in oneself are part of everyone's life. [2] Neff explained that someone who has self-compassion can feel more comfortable in social life and can accept himself as he is; besides, it can also increase wisdom and emotional intelligence. [3]

From the results of 250 journals, it is explained that instilling the value of empathy in the family can develop self-compassion in children. By instilling the value of empathy in children, it is hoped that children will have the ability to position themselves as other people, understand other people's feelings, and control emotions well. This has a great impact on the child's personality so that children can have a self-compassion attitude, where 
children will become individuals who are not selfish in their behaviour or feel sorry for themselves but become individuals who have more compassion for others. The research results that discuss Self-compassion starting from 2016-2020 show that 2018 is the year that has the most research results, in this case, marked by light green, which is the focal point of the discussion. Then in this study, empathy becomes the centre of the discussion, marked by a solid yellow colour. So it can be concluded from the picture that there are still few people who research about this. Therefore, our group took the title for the research material, namely "Instilling Empathy Values in the Family Developing Self-compassion Attitudes in Children", to find out the Development of Selfcompassion Attitudes in Children through Instilling Empathy Values in the family.

\section{Hypothesis:}

1. The cultivation of the value of empathy for selfcompassion is influenced by several factors, namely, gender, age, and personality of the child.

2. There is a correlation of inculcating the value of empathy in the family to the child's self-compassion.

3. By instilling the value of empathy in the family, it impacts the child's personality so that children can develop self-compassion in children.

\section{RESEARCH METHODS}

Researchers not being able to meet directly with all students in this study due to the situational limitations of the pandemic outbreak. So, the researchers used google form as an alternative option to distribute research questionnaires to parents who have early childhood aged 2-6 years. The number of parents who have filled out the researcher's questionnaire is 226 parents. The scale is given consists of a scale for the empathy value variable and a scale for the self-compassion variable. The measurement scale in this study is the Likert scale.

The type of research used in this research is research with a quantitative approach using descriptive statistics and inferential-parametric analysis, specifically used to obtain and test independent variables, dependent variables, and moderator variables. The results were analyzed with the help of Microsoft Excel and the application of Statistical Product and Service Solution (SPSS) version 22 for Windows. This study aims to understand and describe the cultivation of the value of empathy in the family to develop self-compassion in children.

\section{RESULT AND DISCUSSION}

The descriptive statistical analysis aims to describe the data that has been collected. This latest study aims to describe demographic variables, independent variables, and dependent variables. Then the following table is presented.

The descriptive statistical analysis aims to describe the data that has been collected. This latest study aims to describe demographic variables, independent variables, and dependent variables. Then the following table is presented.

Table I. Demographic Information

\begin{tabular}{|c|c|c|c|}
\hline \multirow{2}{*}{ Variable } & & \multicolumn{2}{|c|}{$N=226$} \\
\hline & & $\mathrm{n}$ & $\%$ \\
\hline \multirow{2}{*}{ Gender } & Man & 90 & 40 \\
\hline & girl & 136 & 60 \\
\hline \multirow{5}{*}{ Age } & 2 years & 26 & 11 \\
\hline & 3 years & 24 & 11 \\
\hline & 4 years & 36 & 16 \\
\hline & 5 years & 49 & 22 \\
\hline & 6 years & 91 & 40 \\
\hline \multirow{7}{*}{ Province } & East Java & 209 & 92 \\
\hline & Central Java & 3 & 1 \\
\hline & DKI Jakarta & 5 & 2 \\
\hline & West Java & 6 & 2 \\
\hline & South Kalimantan & 1 & 1 \\
\hline & Maluku & 1 & 1 \\
\hline & Central Sulawesi & 1 & 1 \\
\hline
\end{tabular}

Based on Table I, the distribution of data based on research on gender, age and province of children, it can be concluded that the dominant sex is female, the dominant age is children aged six years, and the province with the most respondents comes from East Java. This is one of the characteristics of taking the hypothesis of the study to measure the effect of inculcating the value of empathy in the family development of self-compassion attitudes in children.

\subsection{Description Of Research Subject}

Description of the subjects involved in the research, based on the data obtained, can be seen in the following table:

Table 2. Number of Subjects by Age

\begin{tabular}{|c|c|c|}
\hline Age & amount & Percentage \\
\hline Two years & 26 & $11 \%$ \\
\hline Three years & 24 & $11 \%$ \\
\hline Four years & 36 & $16 \%$ \\
\hline Five years & 49 & $22 \%$ \\
\hline Six years & 91 & $40 \%$ \\
\hline amount & 226 & $100 \%$ \\
\hline
\end{tabular}


Based on Table 2, the distribution of data based on age in this study includes early childhood because the age range of the subject is 2-6 years. Mansur's statement supports this; early childhood is a group of children who are in a unique process of growth and development [4]. Early childhood is children in the age range of 0-6 years (Law on National Education System in 2003) and 0-8 years according to child education experts. The number of subjects aged two years was 26 children (11\%), subjects aged three years were 24 children (11\%), subjects aged four years were 36 children (16\%), subjects aged five years were 49 children $(22 \%)$, and subjects aged six years amounted to 91 (40\%).

Table 3. Number of Subjects by Gender

\begin{tabular}{|c|c|c|}
\hline Gender & amount & Percentage \\
\hline Man & 90 & $40 \%$ \\
\hline girl & 136 & $60 \%$ \\
\hline amount & 226 & $100 / \%$ \\
\hline Based on Table 3, the distribution of
\end{tabular}
respondents' data on parents who have early childhood based on gender shows that 90 (40\%) subjects are male while female subjects are 136 $(60 \%)$.

\subsection{Factor Affecting Empathy And Self- Compassion}

\subsubsection{Age}

Table 4. Empathy Based on Child's Age

\begin{tabular}{|c|c|c|}
\hline Child Age & amount & Percentage \\
\hline Two years & 716 & $12 \%$ \\
\hline Three years & 654 & $11 \%$ \\
\hline Four years & 941 & $15 \%$ \\
\hline Five years & 1312 & $22 \%$ \\
\hline Six years & 2443 & $40 \%$ \\
\hline amount & 6066 & $100 \%$ \\
\hline
\end{tabular}

Based on Table 4, the distribution of data on children's empathy abilities based on age is known as the age of the child increases, the child's empathic ability will also increase. The ability to empathize will increase with increasing age [5]. This is due to the increasing understanding of perspective, according to Mussen's (1989) statement. [6] Age will also affect the cognitive maturity process in a person. Children who can empathize can be seen from their behaviour [7] that "Children who can empathize will show an attitude of tolerance, compassion, understanding the needs of others, willing to help others, understanding, caring, and able to control his anger." [6] The number of empathy abilities based on the child's age, namely the age of 2 years is 716 $(12 \%)$,

Table 5. Self Compassion Based on Child's Age

\begin{tabular}{|c|c|c|}
\hline Child Age & amount & Percentage \\
\hline 2 years & 707 & $9 \%$ \\
\hline 3 years & 644 & $9 \%$ \\
\hline 4 years & 960 & $13 \%$ \\
\hline 5 years & 1369 & $18 \%$ \\
\hline 6 years & 3834 & $51 \%$ \\
\hline amount & 7514 & $100 \%$ \\
\hline
\end{tabular}

Based on Table 5, the distribution of data on children's self-compassion abilities based on age is known as the older the children, the more mature their self-compassion abilities. Self-compassion is an important aspect of one's maturity. Individuals will achieve a high level of self-compassion when they have reached the integrity stage [8]. The integrity stage is characterized by someone who can do positive self-acceptance. [9] The number of selfcompassion abilities based on the child's age, namely the age of 2 years is $707(9 \%)$, the age of 3 years is $644(9 \%)$, the age of 4 years is $960(13 \%)$, the age of 5 years is $1369(18 \%)$, and the age of 6 years amounted to $3834(51 \%)$.

\subsubsection{Gender}

Table 6. Empathy Based on Child's Gender

\begin{tabular}{|c|c|c|}
\hline Gender & amount & Percentage \\
\hline Man & 2385 & $40 \%$ \\
\hline girl & 3700 & $60 \%$ \\
\hline amount & 6085 & $100 \%$ \\
\hline
\end{tabular}

Based on Table 6, the distribution of children's empathy ability data by gender shows that women have higher empathy than men. Based on their empirical research, which found that women have higher empathy than men [10]. [11] The number of empathic abilities based on the sex of the child, namely the male gender, was $2385(40 \%)$, and the female gender was $3700(60 \%)$.

Table 7. Self Compassion Based on Child's Gender

\begin{tabular}{|c|c|c|}
\hline Gender & amount & Percentage \\
\hline Man & 2471 & $40 \%$ \\
\hline girl & 3698 & $60 \%$ \\
\hline amount & 6169 & $100 \%$ \\
\hline
\end{tabular}


Based on Table 8, the distribution of data on the self-compassion ability of children based on gender, it is known that the amount of self-compassion data for the female sex is higher than the male gender. Neff's statement supports this, self-compassion is influenced by gender. Women are much more thoughtful than men, so women suffer from depression and anxiety twice as much as men [8]. [11] The number of data on children's self-compassion abilities based on gender, namely for the male sex, was 2471 (40\%), while the female gender was 3698 $(60 \%)$.

\subsubsection{Personality}

\subsubsection{1 empathy Based on Personality}

Individuals who have a high need for affiliation will have a high level of empathy and prosocial value, while individuals who have high self-direction, need for achievement and need for power will have a low level of empathy. [12] defines the need for affiliation as warmth and support in relationships with others [12] while Murray states the aspects of the need for affiliation are as follows: 1) Sympathy, namely mutual respect of the circumstances and existence of others; 2) Empathy is a deep feeling of what other people experience; 3) Trust, namely the ability in a person to trust others in relationships; 4) Pleasing others or the desire to please others. Therefore, someone with a high need for affiliation has a high level of empathy [13]. This is indicated by the research data on the first three items, namely item 3 , namely the statement that when there are beggars/buskers, children are invited to give money to them to instil the value of empathy from an early age. From this statement, the results for the strongly agreed options amounted to $90(13 \%)$, the agreed options amounted to $118(17 \%)$, the disagreed options amounted to $16(2 \%)$, and the strongly disagreed options amounted to $2(0 \%)$. Then the second, item 6 , is a statement that children have a sense of caring for others, such as helping friends who need help. From this statement, the results for the strongly agree options are $144(21 \%)$, the agree options are 80 (12\%), the disagree options are $2(0 \%)$, and the strongly disagree options are $0(0 \%)$. Moreover, the third is item 7 , namely the statement that children can share with others, such as sharing food with their friends. From this statement, the results for the strongly agree options are $126(19 \%)$, the agree options are $95(14 \%)$, the disagree options are $5(1 \%)$, and the strongly disagree options are $0(0 \%)$.

Table 8. Empathy Based on Personality

\begin{tabular}{|c|c|c|c|}
\hline Items & Survey Answers & amount & $\begin{array}{c}\text { Percenta } \\
\text { ge }\end{array}$ \\
\hline & Strongly agree & 90 & $13 \%$ \\
\hline
\end{tabular}

\begin{tabular}{|c|c|c|c|}
\hline Item & Agree & 118 & $17 \%$ \\
\cline { 2 - 4 } & Disagree & 16 & $2 \%$ \\
\cline { 2 - 4 } & Strongly Disagree & 2 & $0 \%$ \\
\hline \multirow{3}{*}{ Item } & Strongly agree & 144 & $21 \%$ \\
\cline { 2 - 4 } 6 & Agree & 80 & $12 \%$ \\
\cline { 2 - 4 } & Disagree & 2 & $0 \%$ \\
\cline { 2 - 4 } & Strongly Disagree & 0 & $0 \%$ \\
\hline \multirow{3}{*}{ Item } & Strongly agree & 126 & $19 \%$ \\
\cline { 2 - 4 } & Agree & 95 & $14 \%$ \\
\cline { 2 - 4 } & Disagree & 5 & $1 \%$ \\
\cline { 2 - 4 } & Strongly Disagree & 0 & $0 \%$ \\
\hline \multirow{2}{*}{} & amount & 678 & $100 \%$ \\
\hline
\end{tabular}

\subsubsection{Self-compassion Based on Personality}

Goldberg [14] suggests that there are five personality dimensions that can affect selfcompassion in individuals [15].

\section{a. Extraversion}

This personality dimension is characterized by enthusiasm and enthusiasm [16]. This is evidenced by the questions that have been distributed during the survey on item 9 (Children can do things to help themselves be happy, such as playing a new challenging game). In this item, the answer "often" appears the most, with a percentage of $42 \%$.

Table 9. Self-compassion Based on Personality (Extraversion)

\begin{tabular}{|c|c|c|}
\hline $\begin{array}{c}\text { Survey } \\
\text { Answers }\end{array}$ & amount & Percentage \\
\hline Always & 75 & $33 \%$ \\
\hline Often & 94 & $42 \%$ \\
\hline Sometimes & 52 & $23 \%$ \\
\hline Never & 5 & $2 \%$ \\
\hline amount & 226 & $100 \%$ \\
\hline
\end{tabular}

\section{b. Agreeableness}

This personality dimension has sincerity in sharing, smoothness of feelings, focus on positive things in others. In their daily lives, they appear as kind, cooperative, and trustworthy [17]. This can be seen in item 14 (Children can forgive others who have harmed them), where most of the answers are "often" so that children who often do this have a good personality towards self-compassion. 
Table 10. Self-compassion Based on Personality (Agreeableness)

\begin{tabular}{|c|c|c|}
\hline Survey Answers & amount & Percentage \\
\hline Always & 66 & $29 \%$ \\
\hline Often & 92 & $41 \%$ \\
\hline Sometimes & 63 & $28 \%$ \\
\hline Never & 5 & $2 \%$ \\
\hline amount & 226 & $100 \%$ \\
\hline
\end{tabular}

\section{c. Conscientiousness}

This personality dimension is characterized by the seriousness in doing tasks, being responsible, reliable, and liking order and discipline. In their daily life, they appear as someone present on time, accomplished, meticulous, and likes to do the job to completion [18]. This is evidenced by the questions that have been distributed during the survey on item 16 (Children can admit their mistakes when they make mistakes). The item shows that the answer "often" appears the most with a percentage of $42 \%$, which means that children who often admit their mistakes have a good attitude of responsibility, which in turn has an impact on good self-compassion.

Table 11. Self-compassion Based on Personality (Conscientiousness)

\begin{tabular}{|c|c|c|}
\hline Survey Answers & amount & Percentage \\
\hline Always & 65 & $28 \%$ \\
\hline Often & 94 & $42 \%$ \\
\hline Sometimes & 60 & $27 \%$ \\
\hline Never & 7 & $3 \%$ \\
\hline amount & 226 & $100 \%$ \\
\hline
\end{tabular}

\section{d. Neuroticism}

Neuroticism is often referred to as 'anxiety. The nature of neuroticism is synonymous with negative emotions such as worry, worry, and fear. Children like this are easily nervous in dealing with problems that most people think are trivial. They easily become angry when faced with situations that are not by what they want. In general, they have less tolerance for disappointment and conflict [19]. This is evidenced by the questions that have been distributed during the survey on item 12 (Children try to keep emotions stable even though something disappointing or disturbing happens). The item shows that the answer "sometimes" appears the most with a percentage of $53 \%$,

Table 12. Self-compassion Based on Personality (Neuroticism)

\begin{tabular}{|c|c|c|}
\hline Survey Answers & amount & Percentage \\
\hline Always & 24 & $11 \%$ \\
\hline Often & 63 & $28 \%$ \\
\hline Sometimes & 121 & $53 \%$ \\
\hline Never & 18 & $8 \%$ \\
\hline amount & 226 & $100 \%$ \\
\hline
\end{tabular}

e. Openness

This dimension is closely related to the openness of insight and originality of ideas. Those who are open are ready to accept various existing stimuli with an open perspective because their insight is broad and deep. They enjoy new information, like to learn something new, and are good at creating out-of-the-ordinary activities [20]. This can be seen in item 13 (When they fail to do something, children try to accept it wisely) where most of the answers are "sometimes" with a percentage of $45 \%$, which means that on average, children sometimes try to accept their failures and some do not. Those who cannot accept failure are 11 with a percentage of $5 \%$. This means that most children can still try to accept failure wisely because of the openness of insight they have,

Table 13. Self-compassion Based on Personality (Openness)

\begin{tabular}{|c|c|c|}
\hline Survey Answers & amount & Percentage \\
\hline Always & 48 & $21 \%$ \\
\hline Often & 66 & $29 \%$ \\
\hline Sometimes & 101 & $45 \%$ \\
\hline Never & 11 & $5 \%$ \\
\hline Total & 226 & $100 \%$ \\
\hline
\end{tabular}




\subsection{Correlation Between Empathy and Self- Compassion}

Table 14. Correlation Between Empathy and SelfCompassion

Correlations

\begin{tabular}{|c|c|c|c|}
\hline & & Empathy & $\begin{array}{c}\text { Self } \\
\text { Compassio } \\
n\end{array}$ \\
\hline \multirow[t]{3}{*}{ Empathy } & $\begin{array}{l}\text { Pearson } \\
\text { Correlation }\end{array}$ & 1 & $.223^{\star \star}$ \\
\hline & Sig. (2-tailed) & & .001 \\
\hline & $\mathrm{N}$ & 226 & 226 \\
\hline \multirow[t]{3}{*}{$\begin{array}{l}\text { Self } \\
\text { Compassion }\end{array}$} & $\begin{array}{l}\text { Pearson } \\
\text { Correlation }\end{array}$ & $.223^{\star \star}$ & 1 \\
\hline & Sig. (2-tailed) & .001 & \\
\hline & $\mathrm{N}$ & 226 & 226 \\
\hline
\end{tabular}

**. Correlation is significant at the 0.01 level (2-tailed).

From the output table above, it is known that the value of Sig. (2-tailed) between Empathy (X) and Selfcompassion $(\mathrm{Y})$ is $0.001<0.05$, which means that there is a significant correlation between the empathy variable and the Self-compassion variable.

From the output above, the Pearson Correlation value of the associated variable has two asterisks (**), which means a significant correlation of $5 \%$ or 0.05 .

So, these results show a correlation between empathy and self-compassion, in the sense that the value of empathy in the family can develop self-compassion attitudes in children.

\section{REFERENCES}

[1] Dadan Nugraha, Art Apriliya, and Riza Kharisma Veronicha. (2017). Early Childhood Empathy Ability. Agapedia PAUD Journal. Vol.1 No1.https://ejournal.upi.edu/index.php/agapedia/art icle/viewFile/7158/4758. May 24, 2021

[2] Alhadar, Fahira. (2019). Effect of Self Compassion, Couple's Empathy, Emotional Intelligence, Marriage Duration and Married Age on Marriage Adjustment in Women Who Have Different Cultural Spouses. Thesis. Syarif Hidayatullah State Islamic University.

[3] Ramadhani, Fadhilah. Nurdibyanandaru, Ambassador. (2014). Journal of Clinical Psychology and Mental Health 3 (03), 121.

[4] Khairi, Husnuzziadatul. (2018). Characteristics of Early Childhood Development From 0-6 Years. Color Journal. 2(2): 15-28.
[5] Eisenberg, Nancy, and Paul Henry Mussen. The roots of prosocial behavior in children. Cambridge University Press, 1989.

[6] Ginting, AO (2009). Relationship between Empathy and Cooperative Learning in the Student Learning Process at SMP Negeri 10 Medan. North Sumatra University.

[6] Meidina, Princess. Sofia, Ari. Anggraini, Gian Fitria. Early Childhood Empathy Development.

[7] Borba, Michele. Membangun kecerdasan moral. Gramedia Pustaka Utama, 2008.

[8] Neff, Kristin, and Xe Sands. Self-compassion: Stop beating yourself up and leave insecurity behind New York, NY: William Morrow, 2011.

[9] Nurdiansyah, E. (2017). The Relationship between Self-Compassion and Psychological Well-Being in Prisoners at LPKA Class 1 Blitar (Doctoral dissertation, Universitas Brawijaya).

[10] Toussaint, Loren, and Jon R. Webb. "Theoretical and empirical connections between forgiveness, mental health, and well-being." Handbook of forgiveness (2005): 349-362.

[11] Wardhani, Hapsari Anissa. (2018). Empathy in terms of Parenting Parenting and Gender. Thesis. Muhammadiyah Surakarta university

[12] Muditeshwari, M. (2013). Relationship between Religiosity and Empathy in Christian Youth in Surabaya (Doctoral dissertation, Untag Surabaya).

[13] Nurmala. Kuncoro, Joko. (2021). Need for Affiliation, Personality Introversion and Dependence on Facebook in Students. Projections: Journal of Psychology 6(2), 68-77.

[14] Vesely, William E., Francine F. Goldberg, Norman H. Roberts, and David F. Haasl. Fault tree handbook. Nuclear Regulatory Commission Washington DC, 1981.

[15] Mistian, Mistiani. (2021). Self-Compassion Shadow Teacher. UIN Sunan Ampel Surabaya.

[16] Rosito, Asina Christina. (2018). Personality and Self-Regulated Learning. Journal of Psychology. 45(3): 189-199.

[17] Putriza, Gita Dewi. (2020). The Relationship between Agreeableness Personality Traits and Self Compassion in Late Adolescents. Mercu Buana University Yogyakarta.

[18] Francesca, Laura. (2019). The Correlation of Big Five Personality Types with Student Learning Approaches in the PBL Tutorial Group at the 
Faculty of Medicine, HKBP Nommensen University, Medan.

[19] Choiroh, Fita Bi. (2018). Relationship between Attachment and Self-Compassion with Early Adolescence. UIN Sunan Ampel Surabaya.

[20] Ananda, Deisha. (2019). The Influence of Big Five Personality, Need for Popularity, and Gender on Self Disclosure in MediaSocial Instagram for Students. 